\title{
Ronald Sukenick
}

\section{Dick and Eddie: A Narralogue}

when everything fallS apart it's invariably a sign that at another level everything is Coming together in A New way-as a collecTive Human sEnSibility, this is probably the only optimism available to us-phenomena that seem disruptively random from one point of view may look like a different order from another-whiCh is why rAndomizaTion is a hopeful beginning, an opporTunity, in short, a chancE-in any case, the mind has a low toleRance for disorder-or to put it another way, healthy minds have a hearty appetite for disorder, which they consume at a rapid rate

For example, in the above passage, the embedded capitalizations make no sense, unless you happen to SCAN them as a separate sequence. THE SCATTER method, a Sufi technique, provides a way of discerning non-linear and subliminal order which otherwise seems like disorder. "Scan the scatter," the subliminal message above.

In order to learn to see novel orders, it may become necessary to unlearn old orders. The sequence and placement of words on a page, e.g. Non sequitur is a valuable rhetorical figure in this sense because it is disruptive and forces one to look for novel order. The same is true of ellipsis. Life is often just a series of non sequiturs and ellipses that we bridge to get from one moment to the next. Minimalizing risk, the risk of the unfamiliar, the

strange, the unknown. But suppose we didn't? We'd get from one moment to the next anyway, but some other way, maybe a better way. Some way maybe less glib. More dangerous. Leaps instead of bridges. 
Landing in unexpected places.

This is

what stories are about, or should be.

Unpredictable.

But never ending up nowhere because wherever there is a where there is a there. Too many stories end up where you know they'll end up. He said. Walking over to the

windows
and
gazin
g
thoug
htful
ly at
the
citys
cape.

A

ferry

was

comin

$\mathrm{g}$ in

from

Hobok

en,

the

day

so

clear

he

could

see

its 


\section{flag \\ rigid \\ in \\ the \\ stiff \\ breez \\ e.}

Eddie was not fascinated by his impromptu lecture. But knowing his need to be authoritative about everything, she was willing to indulge him with an attentive air, nodding gravely now and then, all the while wondering how soon, and how, he would get around to making love to her. She supposed he'd brought her up to his fiftieth floor apartment with its spectacular view of the New York skyline for ulterior motives. Or at least she hoped so. It had been fifteen years, and Eddie wasn't assuming anything. It was quite possible that his explosive sexuality had gone grey with his hair. She had once seen him suddenly start making love to a blonde in the middle of a party, the other guests quietly leaving the room one by one when they realized he wasn't going to stop. By the time the blonde realized he wasn't going to stop she was alone with him in the room and mostly undressed. The blonde hadn't been wearing much to begin with so the undressing didn't require a huge effort. But he was adroit and Eddie was fascinated, though not probably as fascinated as the blonde. Eddie felt she had the right to stay and watch since she was his date. It's true it was their last date, but that was for other reasons.

He droned on about order and disorder. Eddie didn't understand any of it. When he talked this way the words seemed to be in a book, then began to scatter on the page, the page itself began to shatter. That was why she'd stopped going out with him fifteen years ago, it was because he gave her the willies. It was practically hallucinatory. She began seeing their conversations instead of hearing them and then the words would dissolve, resolving into alphabets in the air, composed of changing founts depending on his tone and emphasis. Now it was happening again, she had to wonder whether it was worth it, even for the sake of a terrific fuck, like one of their fucks of yesteryear. Eddie blamed herself for being oversexed and getting into pickles like this, while at the same time she had to admit that she liked being oversexed. A lot. Even 
after fifteen years she had this clear memory of his dick. Maybe that was because his name was Dick. Maybe what she was really remembering was his name. She was getting confused. That was the effect he'd always had on her. She suspected it was because he was confused himself.

I'm confused myself, he said, plucking the words, as it were, from her whirling mind. But, he continued, I prefer to be confused. You probably think I'm crazy.

I've always thought you were a little crazy.

You may be right. But I'd argue for a superior epistemological sanity and I'll tell you why. Because it's precisely those moments of deepest confusion that reveal breaks in an inadequate pattern of order, aporia, like the man says, allowing us to explode the clichés of narrative that lead us away from rather than into the data of our experience. And it's exactly those false narratives that drive us crazy by betraying our experience, often to the benefit of the powers that maintain the status quo.

Very intriguing, she ventured.

Take our story, just for an example, he went on. You may have an idea of what is supposed to happen next, I don't. Do we quote renew old bonds? Do we quote disappoint one another's expectations? Do we quote take up where we left off? Do we massage one another's nostalgias? Do we enter into a suicide pact, make passionate love and leap from the fiftieth floor? Or will it be something neither of us could have guessed the moment before?

Let's order in Chinese, she said. I'm hungry.

He slapped her lightly, almost playfully, on the cheek. Could you have foreseen that? he asked, standing over her. None of us know for sure what's going to happen next.

She responded by punching him in the balls, mustering enough leverage from a sitting position so that he doubled over. For example, she said.

To the point, he groaned. Which do you prefer, Szechwan or Cantonese?

Cantonese, it's easier to spell. What was that bit about benefitting the status quo? 
Let's be blunt. The rich and the powerful have a big stake in maintaining things as they are, or failing that, in making sure that any change is managed change, under their management of course. And that includes how you say, what you look, when you hear, even where you feel. It depends on timing. Try changing the look of words on a page twenty years ago and all hell breaks loose. I know, I tried. Try it today and nobody notices because narrative is an ongoing process, and one of the things that goes on is an ongoing process of incorporation. But it's a process like an eddy in a stream that can swirl back to recollect what's gone before and use it in a new cycle in a new way. Time reverses itself all the time, relativistically speaking. Narrative is never straightforward, except in America, or so we like to think. In America narrative drives straight ahead, perpetually on the interstate. Here everything we do is done for the first and last time, if you want to eddy back to the past try Europe. Here the attitude toward tradition is we've done that already, forget it. Everything we do is unprecedented, nothing has a lineage, we reject not only the mother and the father but the very idea of parentage. Fuck the past. The trouble is that makes us all orphans. You can't have a future without a past. That's why we're always on the interstate, which is an undefinable state between the past and the future. That's why it's both interesting and terrifying to be an American. It's like a speeding car with no brakes. The American narrative is not so much an eddy as a tornado, cutting loose with an erratic course across the landscape of time, the most dangerous force in the world. So everything I said before still goes only the stakes are higher.

Speaking of steaks, I'm hungry as a Hungarian, she said, and my appetite for talk is limited.

\section{HALF-TIME INTERLUDE. WE WILL RESUME PLAY SHORTLY, AFTER THE FOLLOWING ANNOUNCEMENT.}

And now, please stand. I would like everyone reading this, or hearing it, to please stand up and raise your right hand. Repeat after me: I fudge obeisance to the snag, of the unwritten snakes of the hemisphere, and to the onion from which it scrams, one masturbation, invisible under snot, with liberty and justice for some. Please be seated. 
They decided to go out for tabouli. He said it was a subliminal craving aroused by the scent of her perfume, which was called Taboo. He said taboos were made to be broken. He said he never let a day go by without breaking some taboo. On principle. Preferably as soon as he got up in the morning. If he let it get too late in the day sometimes he wouldn't get around to it, or at least not till late at night, and sometimes not at all.

Isn't that just a little compulsive? Eddie wondered.

Not compulsive, he replied. That's my job, the job of the, well, what am I exactly? A construction worker. The first step in construction is demolition. It comes hard to most people but actually it's quite easy once you get the hang of it. It looks complicated. The trick is to find the point of leverage. Then one tiny thrust, a little spurt of energy, an involuntary spasm, is enough to send the whole Oedipus tumbling down. Fuck the past. But don't expect any thanks for it. Even though the moment of destruction and the moment of recreation are one. That's why artists are problematic. Recreation for them means problems for us.

Is that it? asked Eddie.

No, that's just the beginning, responded Dick. That's just clearing the ground. Then you have to dig the hole.

The whole what?

That depends. Whatever you see as holistic. It can be a black hole or holy as a swiss cheese.

I prefer it be wholesome.

Yes your holiness. You've always had a moralistic streak. The trouble with you moralists is that your efforts are misplaced. Why tell people what or what not to do when they don't know how they think? Moralists believe that thinking is something like arithmetic, right or wrong, get the logic right and it all adds up. Syllogisms. But let's examine that word. When you realize it's a compound of silly and gism its meaning breaks down. Am I going too far? Do you follow?

At a distance. A great distance.

What I'm talking about is just a different way of looking at things. The way most of us look at them most of the time. Not thinking about 
their meaning. Looking at them instead of through them. This is called the holy see. Why does it seem so crazy then?

They put on their coats and went down in the elevator. She could feel her ears pop as it descended. But instead of going to the restaurant he directed the taxi to the South Street Seaport. There were plenty of restaurants over there also so she didn't complain, but when she found herself at the end of a pier with him she did think to inquire. What the hell are we doing out here?

He didn't answer. There was a light fog over the East River but she could see a small tramp steamer, high in the water, plugging upstream against the current. The fog horns and buoys were hooting and piping in the Upper Bay. Humidity created an illusion of sweatiness on the slightly swaying wooden pilings, as if they were laboring. Just then a large launch pulled in and he ushered her down a long flight of wooden steps. A short man with a limp wearing a yellow plastic slicker helped them onto the boat's lightly rolling deck and into a sizeable cabin. The sailor at the wheel didn't turn around. All they could see of him between his stocking cap and the collar of his pea jacket was a massive neck, purplish and creased like an elephant's trunk. The launch cast off quickly and its prow tilted up as it headed full speed out into the middle of the dark river. Before long they drew abreast of the tramp steamer she'd seen from the pier. Close up her rusty hull looked a lot bigger. She was floating well above the water line, and even in the dim light they could see a good part of the rudder exposed beneath her stern. The name painted on her bow was CYCLONE. A ladder clattered down the scaly side of the hull and they scrambled up. Luckily Eddie was wearing her jeans and Reebok high tops and even with that she felt slightly terrified as she slipped and lurched with the motion of the ship. At the top a sailor grabbed her arm and pulled her on board, Dick close behind. They were shown to the bridge. The captain, peering into the murk below the bow and muttering orders to the sailor at the wheel, didn't deign to greet them.

Why are we here? demanded Eddie of no one in particular. The captain had a full white beard, short, like Hemingway's.

The interesting thing about the rivers around New York is that they're reversible, said the captain. With the tide. He had a deep voice, like Henry Kissinger's without the accent, sepulchral. Today is my birthday, 
he continued, his eyes drilling into the darkness ahead. On my birthday a year ago I was navigating down the Amazon. My ship had no radar, instrumentation was extremely rudimentary. Down there sailing is much like an art form. A feeling of rightness is critical, because things happen too quickly to compute. You have to act before you think, like playing tennis or basketball. Navigating becomes a matter of intuition, of judgment, almost of style. Style is not a question of what you put in, it is based on leaving things out, in this case snags and shallows. Style precedes thought and creates the frame in which new thought can occur. What do you like for breakfast?

Breakfast, come on, said Eddie. I have an appointment on the Upper West Side early tomorrow morning.

Sorry, said the captain. You won't make it.

She turned to Dick. I don't get it, he said. I didn't know this was going to be overnight. I thought it was a trip around the island. It was supposed to be a lark. There must be some misunderstanding, he said to the captain. You can imagine how he felt. A large tug churned past well off their port bow. He thought of signalling but knew it was useless.

Of course, a misunderstanding, said the captain. There always is, that's normal. That's just one reason why the story is always beginning again, forking, heading off in new directions. What exactly is the beginning, middle and end of a voyage on a tramp steamer such as this I ask you? The whole concept is nonsense. You unload at a port while taking on new cargo which is unloaded elsewhere. Every port is end, beginning and middle depending on whether you are looking forward back or around. Or you might best say that we inhabit a permanent middle. Our course? Right now we are headed for Long Island Sound, then past Montauk and Block Island into the open ocean.

What are you telling me? screamed Eddie.

You find that disturbing? said the captain. Some might find it sexy.

I arranged this with my travel agent, said Dick, and you turn out to be some kind of pirate? Or what's the story?

That depends largely on the feedback. If you're missed, that's one thing. If nobody notices, that's another.

You're thinking ransom? asked Eddie. Forget it. 
I'm thinking money, said the captain. I'm going to create a story for you that we can sell to Hollywood. That will justify everything. Give meaning to your life.

What meaning?

The meaning is money. The means is money. The message is money. A long time ago I shipped out under an old Norwegian captain. He idealized the Vikings. He had in his cabin a whole library devoted to the exploits of the Vikings. Rape and plunder. He said they would descend on the coastal towns like a whirlwind, destroying what they could not carry away. Those crazy boys, he would say, shaking his head. We were carrying a cargo susceptible to spoilage, dairy products as I remember, yet he detoured over a hundred miles to pick up the passengers and crew of a pleasure yacht in distress, in face of an oncoming hurricane that he knew might prevent him from retracing his course in a timely way. Without hesitation. Then we had engine trouble, went adrift, radio dead, near run out of food, and drinking water was in short supply. We were down to dog snacks, part of the cargo. Before you knew it we were at one another's throats. The two young women from the yacht were trading their bodies for dog food. After a while there were so little rations some of the men just took their bodies when they pleased. We were devolving into bestiality. The old captain tried to restore order but the sailors knocked him on the head and plundered his cabin. He was dead by the time we were picked up, but the received version was he fell on his head. Twenty-three days adrift. After it was all over one of the young women sold the story to a magazine for a nice sum, I'm told, then got a film option on top of that. Ended up doing endorsements for a dog food company, developed quite a nice bark. So how does it all add up? The captain heaved a sigh. When I began it was all people, he said. Now it's all corporations. So it's important to have a track record, and I can show that I know how to take a catastrophe and turn it into a money making proposition.

Do I understand that you're heading for disaster again? Dick asked quietly.

You get the drift, answered the captain. And that's why I need you two. For human interest. 


\section{FEEDBACK FED BACK}

The Norwegian freighter episode, speaking of human interest, was actually a trip I took with my ex-wife, with whom I remained deeply if ambivalently attached. She died recently of breast cancer. She always used to complain that I didn't put her into my stories. So here she is, now that it's too late.

Other personal messages are embedded in the text. I believe our reality is now largely a corporate one, mediated by the profit drive of the free market in almost every aspect of our lives. Therefore even autobiography has become a commodity, as, to wit, the above.

The story about making love in the middle of a party is true. It happened after a reading I gave at The University of Iowa Fiction Workshop. Maybe it was my way of saying fuck you to the Iowa Workshop, which I didn't like because of its complicity in the literary-industrial complex that manufactures prestige with the power of money. Anyway, it was a memorable fuck, if only because I remember it.

The old captain in fact liked to read about the rape and plunder perpetrated by his ancestors, but he didn't like rape and plunder itself. However it's arguable that in our era the difference between enquote real experience and mediated experience is disappearing. Thanks to the electronic revolution, our experience of the text (or screen) is as real as any other experience. The print world is separable from the mind, but as it becomes continuous with the world of electronic media, the electrosphere-i.e., our reality-the distinction between mediated and unmediated experience begins to blur.

A film was recently made about the true story of stranded travellers in the Andes resorting to cannibalism and the survivors became heros. In Colorado where I live the sole survivor of a snowbound nineteenth century travelling party, though not broadcasting his exploit, was not so lucky, being sentenced by a judge who 
reportedly told him, with some irritation, "There was only three Democrats in Gilpin County, and you, you son of a bitch, you et two of em."

I travelled on the Amazon last year on a passenger ship made from the salvaged nineteenth century hulk of a Scottish steamer powered by a rebuilt engine from a caterpiller tractor. It had no instrumentation at all and at night the captain navigated with the sole aid of a strong flashlight.

I didn't notice the echo between my heroine's name, Eddie, and that of Oedipus. Does this imply some complicated trans-sexual taboo violating ambivalence? Probably. I'll have to think about this.

Suppose we start leaving things out, she Suppose we he answered.

Right here? she asked, as she her blouse. Why under a life boat.

But the weather before they dawn

They were, as a matter of fact in at o'clock, eastern standard The sea was clouds horizon black. The waves began to balance. Soon greenish pallor doubled over the railing
$\begin{aligned} & \text { all day } \\ & \text { When night closed }\end{aligned}$
$\begin{array}{lcc}\text { The radio } & \text { The captain } \\ \text { the life boat } & \text { sea } & \text { now boiling } \\ \text { life preservers } & \text { captain } & \text { lowered } \\ \text { boats } & \text { whirlpool } & \text { going down }\end{array}$ your whole life passes

this is what it's like to move into the end game, was what was going through his mind. She was like an eddy in time that cycled him back fifteen years. He had said goodbye knowing it was a mistake, but sometimes every available option is a mistake. He remembered she cried quietly, not to make a thing of it, and he was surprised that her feeling reflected his, which he had never declared, even really to himself. 
I literally bumped into her in a museum. We were both looking at a Monet painting of water lilies, one of those paintings where the colors swirl about and you can't tell up from down or reality from reflection. But we recognized one another immediately, not that we could exactly place one another, but we knew one another, knew we had been lovers, knew that we had liked one another and instantly knew that we still liked one another. Over coffee we caught up on one another's lives but what was eerie and at the same time vastly reassuring was the intuition that at times time doesn't matter. Even though it does.

None of this was
predictable. A
chance meeting set
off a chain of
speculation and
invented incident
that quickly took
off in directions of
its own. Because
you can never step
in the same river
twice, even though
you are part of the
river. I don't
understand any of
this. I don't need
to. My mission is
transmission. This
is merely data. 
Before I end this I want to say

Tho' you've gained zilch from my work today

That this is a narrative informed by gnosis

Where most stories mainly induce hypnosis

So unless your reading jogs you awake

You know de facto the writing's fake

The truth of fiction is now corrupt

So let it rot while you

WAKE UP! 